\title{
RADIOLOGICAL STUDY OF SACRO-ILIAC JOINTS IN ANKYLOSING SPONDYLITIS WITH REFERENCE TO THE EVOLUTION OF THE DISEASE*
}

BY

\author{
J. FORESTIER AND P. DESLOUS-PAOLI \\ Aix-les-Bains, France
}

(RECEIVED FOR PUBLICATION DECEMBER 20, 1956)

Krebs (1931) stated that, in ankylosing spondylitis, sacro-iliac changes appeared early in radiographs and were almost constant. Since that time the attention of all those interested in the clinical aspects and pathogenesis of the disease has been focused on these radiological changes.

Scott (1936) laid great stress on the value of radiological changes in early diagnosis of the disease, and launched the idea that sacro-iliac arthritis was possibly the initial focus from which the spinal symptoms developed; being a radiologist, he believed that these radiological changes would not be apparent clinically. Forestier, Jacqueline, and Rotés-Querol (1951) described as symptomatic of sacro-iliac involvement a dull pain referred to the buttocks and the posterior aspect of the thighs. These pains were explained by the exhaustive researches of Lewis (1942) and Kellgren (1955).

Forestier (1939) and Forestier and Metzger (1939) have described three stages in the evolution of these radiological changes in the course of the disease,

* This paper was presented at a clinical meeting of the Heberden Society on December 14, 1956. which were confirmed by a later study based on two hundred cases (Forestier, Jacqueline, and RotésQuerol, 1951).

\section{Radiological Changes in the Sacro-iliac Joints}

The essential features of these changes are as follows:

Stage I.-This is observed in the early phase of ankylosing spondylitis, for a period of about 5 to 7 years after the time of apparent onset (and even, in one case, 15 years after the time of onset). It consists of a marginal decalcification along a part or the whole of one or both sacro-iliac joints. The bony contours become hazy and a false widening of the joint spaces appears. Sometimes this widening becomes irregular, with the shape of a rosary-bead, and could be attributed to tuberculous arthritis if the changes were not bilateral from the start.

At the same time, in contrast to the articular transparency, two vertical areas of bony condensation appear in the subchondral zone of the sacrum and ilium (Fig. 1).

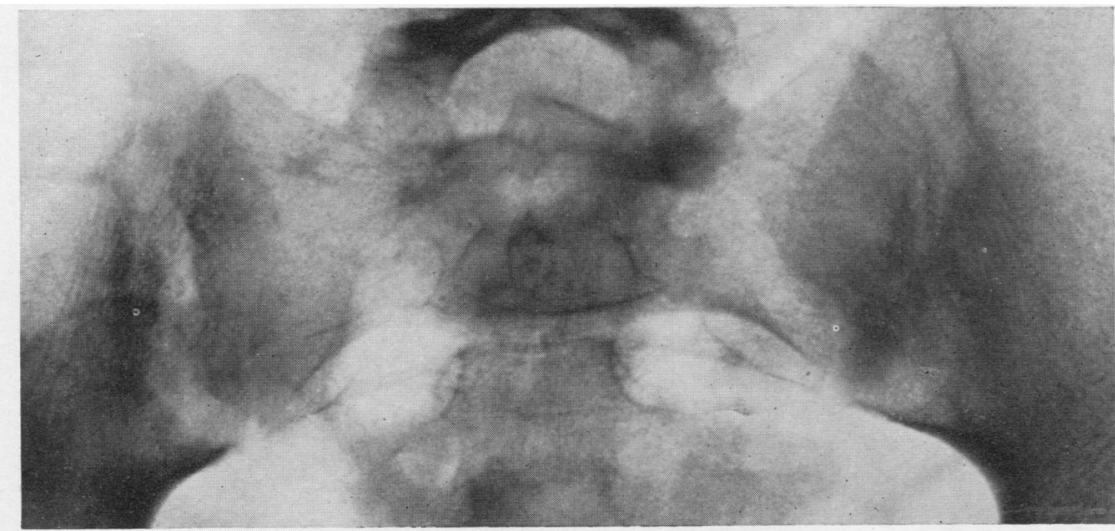

Fig. 1.-Stage I in a 17-year-old male with ankylosing spondylitis of $2 \frac{1}{2}$ years' duration, showing bilateral changes, false widening of articular spaces, and faint periarticular condensation. 
Stage II.-This has been observed at the earliest after 4 years from the time of onset and at the latest after less than 23 years.

The joint space may be partly or wholly eroded. There is a reconstruction of the adjacent bone for as much as 1 or $2 \mathrm{~cm}$. mostly on the iliac aspect. Bony condensation is very marked, but is irregular and mottled with many small decalcified spots (Fig. 2).

Stages I and II are characteristic of ankylosing spondylitis, and in typical cases it cannot be confused with the changes caused by any other disease.

Stage III.-This is the terminal stage and, since the specific changes described in Stages I and II have disappeared by the time it is completed, it is not pathognomonic of ankylosing spondylitis.

At this stage the joint space has entirely disappeared; there is a bony fusion of the lower two-thirds of the joint space, and occasionally minimal remains of the latter are visible. Bony condensation has vanished. In long-standing cases, very fine bony streaks can be seen starting from the inter-apophy- seal joints, crossing the sacro-iliac space obliquely, and dispersing around the upper part of the acetabulum (Fig. 3).

This stage was not seen until 7 years after the time of onset; all cases observed after 23 years displayed whole or partial bony ankylosis of the sacro-iliac joints.

One may infer, therefore, that in the period from 8 to 15 years after the time of onset any one of these three stages may be encountered, irrespective of the age or sex of the patient (Fig. 4, opposite).

\section{Evolution of the Disease Process}

A survey of three hundred of our cases, chosen because they had been regularly observed for a period of not less than 6 years, has recently been carried out. The question was posed whether the appearance of sacro-iliac synostosis means that the evolutionary process of ankylosing spondylitis is terminated, and whether it has therefore a prognostic value?

Sacro-Iliac Changes.-Our observations on the

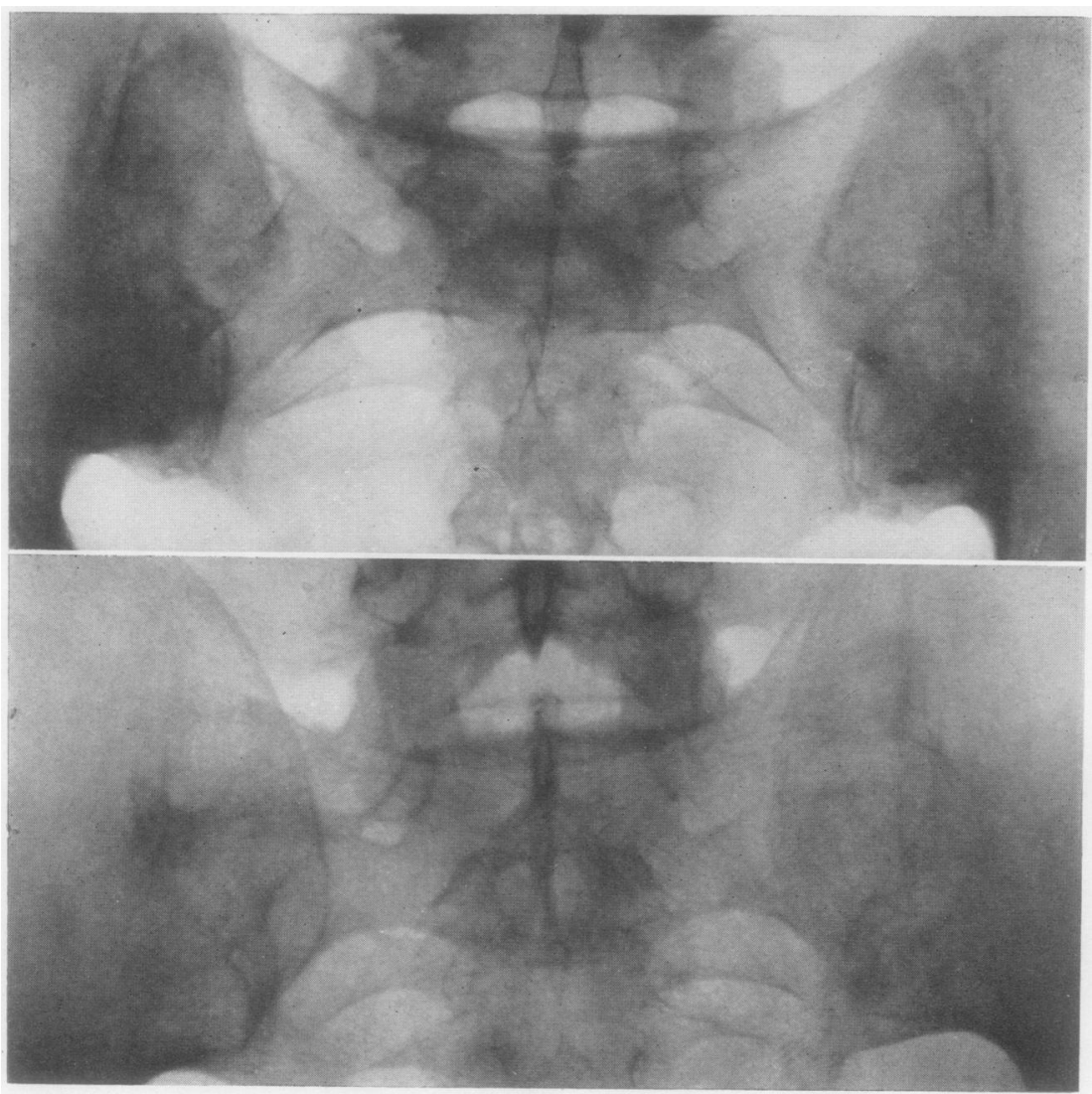

Fig. 2.-Stage II in a 42-year-ol male with ankylosing spondylit of 20 years' duration. The joint spaces are hardly visible and are covered by a zone of condensation with mottled appearance.

Fig. 3.-Stage III in a 56-year-old male with ankylosing spondylitis of 34 years' duration, showing bony ankylosis of both sacro-iliac joints.

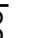




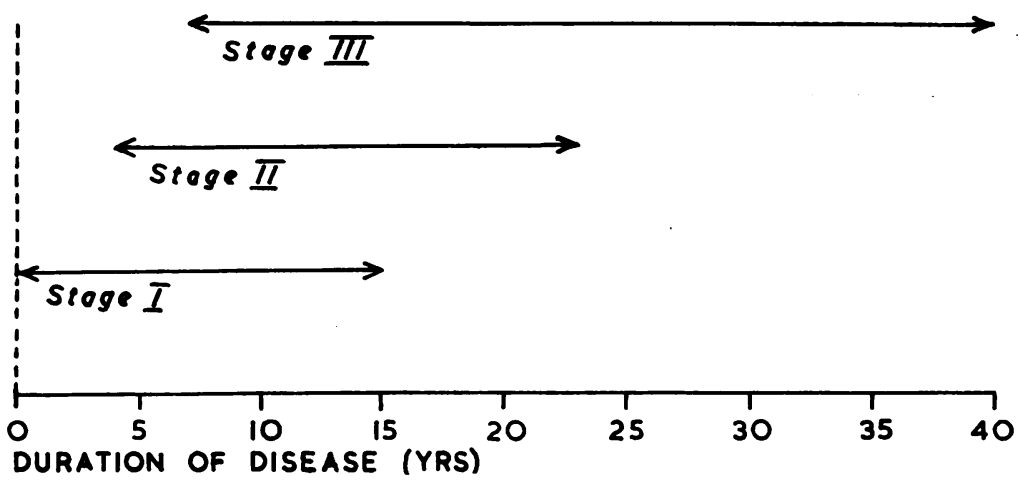

Fig. 4.-Diagram, based on one hundred cases, showing the three stages of evolution of the disease in which the three stages of radiological sacro-iliac changes may be encountered.

clinical cycle of the disease is 19 years. In a few cases, we were able to follow our patients before and after sacro-iliac ankylosis developed, and in each of these the evolution of the disease persisted unchanged.

We can conclude, therefore, that the fact that bony ankylosis of the sacro-iliac joints has appeared does not mean that the ankylosing spondylitis is permanently in remission.

sacro-iliac changes show that the time taken for bony ankylosis to develop varies from 7 to 23 years. We have been able to follow up 54 cases with numerous radiographs, and can therefore establish the average length of this cycle with some precision as 14 years, though it is difficult to determine accurately the time of onset of the disease from purely clinical observations. Romanus (1953) also emphasized this point. Of our 54 cases which showed complete bony ankylosis of the sacro-iliac joints (Stage III), 21 could be considered as in permanent remission, while in the remaining 33 the disease was still active. It appears, therefore, that bony ankylosis of the sacro-iliac joints is not a sign that the process of evolution of the ankylosing spondylitis has ceased.

The establishment of the final stage of development may be more accurately based on the following considerations:

(1) The disappearance of the spinal and referred pains connected with the inflammatory process of the disease; this pain must be distinguished from the static pains caused by postural defects;

(2) The return to normal of the erythrocyte sedimentation rate, which is almost always raised (by more than 75 per cent.) during the process of evolution of ankylosing spondylitis.

When these two criteria have remained negative for 2 years it may be accepted that the disease process is definitely arrested.

Clinical Developments.-The average duration of the clinical evolution of our 21 (Stage III) cases was 19 years, but the range was very wide.

Thus the average length of the complete cycle of sacro-iliac involvement up to the stage of bony ankylosis is 15 years, but the average length of the
Other Diagnostic Factors.-In a further study of these 21 arrested cases, we tried to find out what other factors could be considered as diagnostic of permanent remission of the disease process. In an analysis of the clinical symptoms, $x$-ray findings, sex, age, occupation, and age at onset, the only common factor was complete bony ankylosis of the spine (from occipital bone to sacrum) and of the sacro-iliac joints. There was only one exception in the 21 cases; we know of a very few other cases in which the disease appears to be arrested when the bridging of the intervertebral spaces (syndesmophytosis) is not entirely completed, and in only two of these had the sacro-iliac joints not undergone bony ankylosis.

Relationship between Age of Patient and Stage of Evolution.-In the group of 21 stabilized patients, we found that a wide gap existed between the youngest (25) and the oldest (65); nine of them were aged between 45 and 55 years (average of the whole group 47). Thus the majority were at the age of hormonal change (menopause and andropause), and, as ankylosing spondylitis generally starts at the age of puberty, it may be noted that its evolution is usually completed during the period of sexual activity.

Differential Diagnosis.- Rheumatoid arthritis may start at any age (personally we have observed it starting at 14 months and after 80 years), and this is therefore another point of differentiation between the two diseases.

\section{Summary}

The study of three hundred cases of ankylosing spondylitis followed-up for a period of 6 to 23 years has given rise to the following observations: 
(1) The development of bony ankylosis of the sacro-iliac joints as revealed by radiography is not related to the arrest of the disease.

(2) As a rule, all patients in whom the disease has been quiescent for several years show a complete bony ankylosis of the spine and the sacro-iliac joints.

(3) The average period of evolution of ankylosis of the sacro-iliac joints is 14 years.

(4) The period of clinical evolution of ankylosing spondylitis varies greatly, the average being 19 years.

(5) The disease usually runs its course during the period of sexual activity in both men and women.

\section{REFERENCES}

Forestier, J. (1939), Radiology, 33, 389.

Forestier, Jueline, F., and Rotés-Querol, J. (1951). "La spondylarthrite ankylosante". Masson, Paris. (Eng. trans. by A. U. Desjardins, 1956. Thomas, Springfield, Ill.)

Kellgren, J. H. (1955). In "Textbook of the Rheumatic Diseases", 2nd ed., ed. W. S. C. Copeman, chap. 3. Livingstone, Edinburgh.

Krebs, W. (1931). "Klinik der sogenannten rheumatischen Wirbelsaulen-erkrankungen Rheumaproblem", vol. 2, p. 103 Thieme, Leipzig.

Lewis, T. (1942). "Pain". Macmillan, New York.

Romanus, R. (1953). "Pelvo-spondylitis ossificans in the Male and Genito-urinary Infection”. Acta med. scand., 145, Suppl. 280.

Scott, S. G. (1936). Brit. J. Radiol., 9, 126.

Etude radiologique des articulations sacro-iliaques dans la spondylarthrite ankylosante, en rapport avec l'evolution de la maladie

RÉSUMÉ

L'étude de 300 cas de spondylarthrite ankylosante, suivis durant des périodes de 6 à 23 ans, a permis les observations suivantes:
(1) Le développement de l'ankylose osseuse des articulations sacro-iliaques, tel qu'il est révélé par la radiographie, est sans relation avec l'arrêt de la maladie.

(2) Généralement, tous les malades chez lesquels la maladie a été inactive depuis plusieurs années, montrent une ankylose osseuse complète de la colonne vertebrale et des articulations sacro-iliaques.

(3) La durée moyenne de l'évolution qui aboutit à l'ankylose des articulations sacro-iliaques est de 14 ans.

(4) La durée de l'évolution clinique de la spondylarthrite ankylosante varie beaucoup, la moyenne étant de 19 ans.

(5) La maladie suit d'habitude son cours durant la période d'activité sexuelle des hommes comme des femmes.

Estudio radiológico de las articulaciones sacro-iliacas en la espondilartritis anquilosante, con referencia a la evolución de la enfermedad

\section{Sumario}

El estudio de 300 casos de espondilartritis anquilosante, seguidos durante períodos de 6 a 23 años, permite las observaciones siguientes:

(1) El desarrollo de anquilosis ósea de las articulaciones sacro-ilíacas, según su aspecto radiológico, no tiene relación con la parada de la enfermedad.

(2) Generalmente, todos los sujetos con la enfermedad inactiva desde varios años revelan una anquilosis ósea completa de la columna vertebral y de las articulaciones sacro-ilíacas.

(3) La duración media de la evolución de la anquilosis de las articulaciones sacro-ilíacas es de 14 años.

(4) La duración de la evolución clínica de la espondif artritis anquilosante es muy variable, con un promedis de 19 años.

(5) La enfermedad sigue generalmente su curso durante el período de actividad sexual tanto de los hombres como de las mujeres. . 